\title{
Staj Yapan Öğrencilere Yönelik Cinsel Taciz: Otel İşletmeleri Örneği
}

\author{
Sexual Harrasment Toward Intern Students in Hotels
}

Doç. Dr. Kamil UNUR

Mersin Üniversitesi

Turizm Fakültesi

E-posta: kunur@yahoo.com

Orcid Id: 0000-0003-2992-7427
S. Ceylin ŞANLI

Mersin Üniversitesi

Sosyal Bilimler Enstitüsü

E-posta: ceylin_sanli@hotmail.com

Orcid Id: 0000-0001-7339-0538

\section{Öz}

$\mathrm{Bu}$ araştırmanın amacı, turizm işletmelerinde mevsimlik olarak çalışan ya da staj yapan öğrencilerin çalıştıkları süre içinde misafirler tarafından gördükleri uygunsuz davranışların düzeyini ve eğer karşılaşıldıysa bu durumdan duyulan rahatsızlık derecesini belirlemektir. Bu kapsamda Mersin Üniversitesi Turizm Fakültesinde öğrenim gören Turizm İşletmeciliği Bölümü öğrencilerine anket uygulanmıştır. 168 kullanılabilir anket üzerinden veriler analiz edilmiştir. Analiz sonuçları misafirlerden staj yapan ya da mevsimlik olarak çalışan öğrencilere yönelik bir cinsel tacizin yaşandığı, ancak bunun boyutlarının çok ciddi olmadığını göstermektedir. Ayrıca erkek stajyer ya da mevsimlik olarak çalışan öğrencilerin, kadın öğrencilere oranla daha fazla cinsel tacize uğradıkları çalışmanın ilginç sonuçlarından biridir. Bir başka sonuç ise, konaklama işletmelerinde staj yapan ya da mevsimlik olarak çalışan öğrencilerin misafirlerin cinsel tacizlerinden ciddi oranda rahatsızlık duymamalarıdır.

Anahtar Kelimeler: Cinsel Taciz, Otel işletmesi, Stajyer öğrenci.

\section{Abstract}

The aim of this research is to determine the level of inappropriate behavior of the customers to the students who work as seasonal employees or apprentice in tourism enterprises and the level of disturbance of the students. In this context, a questionnaire was applied to the students of Department of Tourism Management in Mersin University. Data were analyzed on 168 usable surveys. Findings shows that students who work as seasonal employees or do internship in hotels are sexually harassed by the guests at a low or moderate level. One of the interesting findings of this study is that male students who work as apprentice or seasonal employees get more sexual harassment than female students. Another finding is that students don't feel serious discomfort by sexual harassment of guests.

Key Words: Sexual Harassment, Hotel, Intern student. 


\section{Giriş}

Günümüzde cinsel taciz her iş ortamında sıklıkla ortaya çıkan bir olgudur. Özellikle hizmet üreten işletmelerin doğası, cinsel taciz için bir zemin oluşturmaktadır. Çünkü hizmet üretim süreci çoğunlukla müşterinin sürece katılımıyla gerçekleşmektedir (Gilbert vd., 1998: 49). Bu duruma üretim ve tüketimin eş zamanlığı da denmektedir. Konaklama işletmeleri de hizmet üreten işletmeler olduğu için söz konusu eşzamanlılık ve misafirler ile işgörenler arasında yakın ve yüz yüze ilişkiler sürekli yaşanmaktadır (Poulston, 2008: 233).

Otellerde zorunluluk olan yakın ve yüz yüze ilişkiler zaman zaman misafir ile işgören arasında istenmeyen olayların yaşanmasına neden olabilmektedir. Bu olaylardan bir tanesi de cinsel tacizdir. Cinsel taciz yalnızca örgüt içerisinde çalışandan çalışana ya da yöneticiden çalışana yönelik olarak gerçekleşmemektedir. Çalışandan müşteriye ya da müşteriden çalışana yönelik olarak da gerçekleşebilmektedir (Hughes ve Tadic, 1998: 207). Müşterilerin çalışanlara yönelik cinsel tacizi genellikle organizasyon ve çalışanlar tarafından görmezden gelinmekte, hatta reddedilmektedir. Örgütler, müşterilerin bu davranışlarını hizmet bağlamında kişilerarası etkileşiminin doğal bir parçası olarak görmektedirler (Yagil, 2008: 150). Türkiye gibi turizmi ağırlıklı olarak aktif dış turizmden oluşan, yani gerek turist sayısı gerekse turizm geliri açısından yabancı turistlerin Türk turizminin yarıdan fazlasını oluşturduğu düşünüldüğünde (TUİK, 2016), işgörenlerle turistlerin kültürleri ve cinselliğe bakış açıları farklı olabilmektedir. Bu durum bazen tacizi zorlaştırabileceği gibi bazen de kolaylaştırabilecektir.

Turizm işletmeciliği konusunda eğitim alan öğrenciler mesleki bilgilerini artırmak amacıyla otel işletmelerinde yaz dönemlerinde stajlarını yapmakta, stajlarını yapmış olan öğrenciler ise çalışmaktadır. Bu kapsamda bu araştırma turizm işletmelerinde staj yapan ya da çalışan öğrencilerin müşteriler tarafından ne sıklıkla uygunsuz davranışlara maruz kaldıklarını ve uygunsuz davranışlara maruz kalan öğrencilerin bu davranışlardan ne derece rahatsız olduklarını belirlemek amacıyla yapılmıştır. Cinsel taciz konusunda otel işletmelerinde doğrudan misafirlerin çalışanları taciz ettiğine yönelik tasarlanmış bir çalışmaya rastlanılmadığı için bu çalışmanın alan yazına katkısı olacağı düşünülmektedir.

\section{Literatür Taraması}

Cinsel taciz oldukça geniş bir kavramdır ve herkes tarafından farklı algılanmaktadır. Bu nedenle cinsel tacizle ilgili ortak bir tanımdan bahsetmek mümkün değildir (Yeşiltaş, 2005: 147). TDK (Türk Dil Kurumu, [TDK], 2017) cinsel tacizi "Ahlaksızca, ulu orta veya gizlice söz ve davranışlarla karşı cinse eziyet etme, tedirginlik ve sıkıntı verme" ve "Çalışma hayatında ekonomik güç, üst makam veya başka etkili bir göreve sahip olanların, genellikle karşı cinsi ahlak dışı birtakım tutum ve davranışlarla cinsel yönden sıkıntıya sokup rahatsız etmesi" olarak iki ayrı şekilde tanımlamıştır. Bu kavramı ilk defa 1979 yılında 'Sexual Harassment of Working Women' adlı kitabında Catherine MacKinnon "eşit olmayan bir güç ilişkisi bağlamında cinsel intiyaçların istenmeyen biçimde uygulanmasıdır" (Sherwyn vd., 2001: 47) şeklinde tanımlamıştır. Oktay (2012: 75 ) ise cinsel tacizi; "saldırgan, utandıran, korkutup sindiren, gözdağı veren veya aşağılayıcı olan, istenmeyen veya davet edilmeyen herhangi bir cinsel davranıştır" şeklinde tanımlamıştır.

Tanımlardaki çeşitliliğin nedeni hangi davranışların cinsel taciz olarak algılandığı ve kabul edileceği konusunun hala tartışılıyor olmasıdır (Yeşiltaş, 2005: 149; 
Mimaroğlu ve Özgen, 2008: 324). Powell (1983: 116) çalışmasında uzun süreli bakmayı, flört etmeyi, imalı jestleri, dokunmayı, cinsel önermeleri ve cinsel ilişkileri cinsel taciz olarak kabul edilebilecek davranışlar olarak belirtirken; Williams ve arkadaşları (1999: 73) ise flört, cinsel şakalaşma ve diğer cinsel etkileşimlerin iş organizasyonlarında yaygınlaştığını ve bu etkileşimlerin hepsinin taciz veya saldırı oluşturmadığını, çalışanların bu etkileşimleri eğlenceli bulduğunu belirtmiştir. Ancak literatürde genel kabul gören, cinsellik içeren ifade ve imalar, içinde pornografik içerikli fıkra veya resimlerin yer aldığı elektronik posta ve dokümanlar, istenmeyen çimdiklenme, okşanma gibi fiziksel dokunuşlar, bir tarafın istemediğini belirtmesine rağmen sürekli olarak yinelenen flört teklifleri, cinsel içerikli şakalar ve laf atmalar, fiziksel baskı, zorlama ve tecavüz işyerinde cinsel taciz olarak kabul edilen davranış örneklerinden olduğudur (Atman, 2003: 335; Solmuş, 2005: 2).

İ̧ yerinde cinsel taciz hem gelişmiş, hem de gelişmekte olan ülkelerde gizli kalmış bir sorun olarak ortaya çıkmaktadır (Atman, 2003: 335). Eurofound' un Dördüncü Avrupa Çalışma Koşulları Araştırma raporuna göre, Çek Cumhuriyeti'nde kadın çalışanların \%10' u; Norveç' te \%7' si; Türkiye ve Hırvatistan'da \%6'sı; Danimarka, İsveç, Litvanya ve İngiltere' de \%5'i İtalya, İspanya, Malta ve Kıbrıs' ta \%1'den daha azı cinsel tacize uğradıklarını bildirmişlerdir (Eurofound, 2007: 37). Ayrıca Türkiye İstatistik Kurumu (TUIK) istatistiklerine göre Türkiye' de 2008 yılında 9626 kadın, 350 erkek toplam 9976 kişi cinsel taciz suçundan mahkemeye başvurmuştur (TUİK, 2008). Cinsel tacizin sonuçları mağdurlar için, hem psikolojik stres hem de somut iş avantajlarının kaybı açısından oldukça dramatik ve şiddetli olabilmektedir (Husbands, 1992: 537). Sosyal ve psikolojik nedenlerle ve işini kaybetme tehdidi ve korkusu altında olan mağdurların ortaya çıkmaması cinsel tacizin gerçek boyutlarını belirlemeyi zorlaştırmaktadır (Gerni, 2001: 21; Mkono, 2010. 730). Büyük bir olasılıkla cinsel taciz istatistiklerde yer alan rakamlardan çok daha yüksek bir oranda gerçekleşmektedir.

Cinsel taciz her ülkede yaşandığı gibi her sektörde de yaşanmaktadır. Erdemir ve arkadaşları (2011) hemşirelerin \%71,7' sinin hastalar tarafından cinsel tacize uğradığını, Gerni (2001) bankacılık sektöründe çalışan kadınların \%35,4'ünün cinsel tacize uğradığını, Oktay (2012) ise mesleki yaşamları sürecinde kadın öğretmenlerin \%13,4'ünün, erkek öğretmenlerin ise \%8' inin cinsel taciz davranışıyla karşılaştığını belirtmiştir. Lin (2006) ise Tayvan' da gerçekleştirdiği çalışmada konaklama işletmelerinde staj yapan öğrencilerin \% 97'sinden fazlasının en az bir kez cinsel tacizle karşılaştığını belirtmiştir.

Iş yerinde hem erkek, hem de kadın cinsel tacize uğrayabilmektedir. Cinsel tacizin sadece karşı cinsten olması gerekmemektedir. Cinsel taciz erkek ile kadın, kadın ile kadın ve erkek ile erkek arasında da gerçekleşebilmektedir (Maypole ve Skaine, 1983; Yeşiltaş, 2005:148). Toplumda cinsel tacizin erkeklerden kadınlara yönelik olduğu yönünde bir algı bulunmaktadır. Ancak çalışmalarda cinsel tacizin kadınlardan erkeklere yönelik olarak da gerçekleşebildiğini ortaya konmaktadır (Wayne vd., 2001: 179). Webster (2002: 119) tacizcinin kadın olması durumunda erkeklerin kadınlara oranla daha toleranslı olabildiklerini belirtmektedir. Tacize uğrayan erkekler açısından cinsel taciz hem taciz edenin kadın olmasından kaynaklı 'kendisini bir kadına karşı koruyamadı' düşüncesi ile hem de kendilerinin eşcinsel gibi yargılanabilme intimali nedeniyle daha az ortaya çıktığını söylemektedir. Bir başka söylemle, cinsel tacize uğrayan erkekler daha az şikayetçi olmaktadır (Quinn ve Lees, 1984: 43). Bu durumun bir başka nedeni ise erkeklerin bu tür cinsel içerikli davranışları kadınlara göre daha az cinsel taciz olarak algılamalarıdır (Blumenthal, 1998). 
Literatürde genel olarak işyerinde cinsel taciz iki gruba (Schneider vd., 1997; Kane-Urrabazo, 2007) ayrılmaktadır. Bunlardan birincisi; basitçe bir şey karşılığında bir şey istemek anlamına gelen 'Bedelli taciz'dir(Quid pro quo) dir (Brase ve Miller, 2001: 242). Bedelli tacizde cinsel amaçlı bir tehdit ve/veya rüşvet söz konusu olmaktadır (Özdemir, 2006: 88). İkinci grup taciz ise 'Kötü ortam oluşturan taciz' ya da 'Düşmanca iş ortamı' (hostile work environment) olarak isimlendirilmiştir. Bu cinsel taciz tipinde ise cinsel içerikli söz veya davranışlar, bireyin çalışma performansına müdahale etmekte ve ahlak dışı, saldırgan, utanç verici bir çalışma ortamı yaratmaktadır. Düşmanca iş ortamı, istenmeyen cinsel temas, dokunuş ve sözleri de kapsamaktadır (Özdemir, 2006: 88). Literatürdeki genel kabulün aksine Lu ve Kleiner (2001) cinsel tacizi bedelli taciz, fiziksel taciz, sözlü taciz, sözsüz taciz ve çevresel taciz olmak üzere beşli bir gruplandırmaya tabi tutmuştur. Fiziksel taciz istenmeyen dokunma, okşama ve öpmeyi; sözlü taciz cinsel içerikli şakaları, kişinin bedenine yönelik yorumları; sözsüz taciz göz teması ve mimikleri (vücuda bakma, kötü bakışlar atma, ıslık), el ve ağız hareketlerini, çevresel taciz ise cinsel içerikli resim ve objeleri ifade etmektedir.

Cinsel taciz literatürde farklı değişkenlerle birlikte ele alınmış ve cinsel tacizin altında yatan nedenler ve cinsel tacizin sonuçları belirlenmeye çalışılmıştır (KauppinenToropainen ve Gruber, 1993; Fitzgerald vd., 1997; Harned vd., 2002). Yapılan çalışmalarda işyerinde cinsel tacizin genellikle güç mesafesiyle ilişkilendirildiği görülmektedir (Mimaroğlu ve Özgen, 2008; Yücel ve Koparan, 2010). Güç mesafesi, bir toplumdaki insanların gücün dağılımındaki eşitsizliği kabul etme derecesini ifade etmektedir (Robbins ve Judge, 2012: 150). Özellikle yüksek güç mesafesi olan ülkelerde, bu güç cinsel istismar amaçlı kullanılmakta ve cinsel taciz olasılığı daha da artmaktadır (Luthar ve Luthar, 2002: 275; Wasti ve Cortina, 2002: 396). Luthar ve Luthar (2007: 172) güç mesafesi yüksek olan ülkelerde erkeklerin kadınları gözlediklerini (gözleriyle ya da fiziksel olarak takibe aldıkları) ve kendi çıkarları doğrultusunda kadınlara güç kullandıklarını belirtmiştir. Bu görüşe göre cinsel taciz günlük hayatın her alanında yaşanmaktadır. Bu alanlardan bir tanesi de işyerleridir. Cinsel tacizin yaşanmasının altında ataerkil toplum yapısı yatmaktadır. Buna bağı olarak da işyerlerinde genellikle genç, çekici ve deneyimsiz kadınlar tacize daha çok uğramaktadır (Quinn ve Lees, 1984: 41).

İşyerinde cinsel taciz, mağdurlar açsından, saldırı sonrası yaşadıkları uykusuzluk, bulantı, irkilme, kâbus gibi bireysel problemler (Crull, 1982: 541; Gölge, 2005: 20; Eyüpoğlu, 2008: 61) ile iş tatminsizliği, işten ayrılma niyeti gibi örgütsel problemler (Fitzgerald vd., 1997; Harned vd., 2002) de doğurmaktadır. Bunun sonucunda işgören devir hızı yükseleceği gibi, diğer çalışanlar açısından verim kaybı da yaşanacaktır. İşletme açısından ayrılan personel başarılı bir çalışan ise işletmenin rekabet gücü düşebileceği gibi çalışan personel için yapılan eğitim giderleri de boşa gitmiş olacaktır (Yeşiltaş, 2005: 150). Yapılan çalışmalarda ayrıca cinsel tacizin iş kaybı (Coles, 1986); iş tatminsizliği (O'Farrell ve Harlan, 1982); olumsuz ruh hali ve düşük motivasyon, ilgisizlik, düşük iş performansı, azalan örgütsel bağlılık, artan iş stresi (Barling vd., 2001; Chan vd., 2008) gibi olumsuz sonuçlar doğurduğu da belirlenmiştir.

\section{Araştırmanın Yöntemi}

$\mathrm{Bu}$ araştırmanın amacı, turizm işletmelerinde çalışan ya da staj yapan öğrencilerin çalıştıkları süre içinde misafirler tarafından gördükleri uygunsuz davranışların düzeyini ve eğer karşılaşıldıysa bu durumdan duyulan rahatsızlık derecesini belirlemektir. Araştırmada veriler anket formu aracılığıyla toplanmıştır. Anket formunda demografik 
soruların yanı sıra öğrencilerin çalıştıkları ya da staj yaptıkları otellerde misafirler tarafından gördükleri uygunsuz davranışların ölçülmesi amacıyla Reilly ve arkadaşları (1986) tarafından yapılmış konu ile ilgili çalışmadaki maddelerden yararlanılarak hazırlanan ölçek kullanılmıştır. Ölçek maddelerindeki yanıt kategorileri sıklık derecesi için "1= Hiç", "2 = Ara Sıra", "3= Bazen", "4= Çoğunlukla", "5= Her Zaman"; karşılaşıldıysa rahatsızlık düzeyi için "1 = Hiç", "2 = Biraz", "3 = Orta Düzeyde", "4 = Epey" ve " 5 = Çok Fazla" olarak belirlenmiştir.

Araştırmanın evrenini Mersin Üniversitesi Turizm Fakültesinde öğrenim gören Turizm İşletmeciliği bölümü 2., 3., ve 4. sınıf öğrenciler (450 kişi) oluşturmaktadır. Hazırlık sınıfı ve 1. sınıflar henüz otel işletmelerinde çalışmadıkları için araştırma dışında tutulmuştur. Veriler Şubat 2017 - Mart 2017 tarihleri arasında toplanılmıştır. Örneklem büyüklüğünün hesaplanılmasında " $\mathrm{n}=\frac{N \cdot \sigma^{2} \cdot z^{2}}{(N-1) \cdot H^{2}+Z^{2} \cdot \sigma^{2}}$ " formülünden yararlanılmıştır (Ural ve Kılıç, 2011: 47). Örneklem büyüklüğü 142 kişi olarak belirlenmiştir. Analizler 168 kullanılabilir anket üzerinden yapılmıştır. Analizlerde frekans analizi, faktör analizi, güvenilirlik analizi ve t-testi kullanılmıştır.

\section{1. Ölçeğe Ait Geçerlilik Analizi}

Ankette yer alan cinsel taciz ölçeğinin yapısal geçerliliğini test etmek amacıyla açıklayıcı faktör analizi yapıımıştır. Verilerin faktör analizine uygunluğunu saptamak amacıyla Kaiser-Meyer-Olkin ve Barlett Küresellik testi uygulanmıştır. Faktör sayısının tespitinde özdeğerlerin birden büyük olmasına, madde yüklerinin en az 0,40 olmasına, her faktörün en az üç maddeden oluşmasına dikkat edilmiş ve Varimax döndürme metodu kullanılmasına karar verilmiştir.

Analiz sırasında ölçekte yer alan "Misafirler bana cinsel içerikli materyaller (dergi, fotoğraf vb.) gösterdi.", "Misafirler bana kasıtlı olarak dokundular ya da fiziksel temasta bulundular.", "Misafirlerin yurtdışına götürme teklifleriyle karşılaştım.", "Misafirler tarafından öpülmek, okşanmak, makas almak gibi girişimlerle karşılaştım.", "Misafir tarafından tehdit edildiğim için cinsel faaliyetlerde bulundum.", "Misafirlerle işimi elimde tutmak için cinsel faaliyetlerde bulundum.", "Misafirlerle istediğim için birlikte oldum." ve "Misafirlerle değişik bir deneyim yaşamak için birlikte oldum." maddeleri özdeğerleri $0,5^{\prime}$ in altında olduğu için analizlerden çıkartılmıştır. Daha sonra tekrarlanan analiz sonrasında cinsel taciz ölçeğinin Kaiser-Meyer-Olkin (KMO) değeri 0,884; Barlett's Küresellik Testi için Ki-Kare 3501,803 olarak tespit edilmiştir. Bu bilgiler ışığında ölçeğin faktör analizine uygun olduğu söylenebilir. Uygulanan faktör analizi sonucunda 4 faktör altında toplanan ölçeğin toplam varyansın \%69,476' sını açıkladığı bulgulanmıştır. Tablo 1' de cinsel taciz ölçeğine uygulanan faktör analizi sonucu sunulmuştur.

Faktör tablosunda da görüldüğü gibi, "ilgili tavırlar ve eylemler" olarak adlandırılan birinci faktör, 9 maddeden oluşmakta ve toplam varyansın \%21,479'sını açıklamaktadır. 'Bir şey karşılığında bir şey isteme ve fiziksel saldırı' olarak adlandırılan ikinci faktör ise 6 maddeden oluşmakta ve toplam varyansın \%19,026' sını açıklamaktadır. Toplam varyansın \%16,968' ini açıklayan ve 6 maddeden oluşan üçüncü faktör "Müstehcen tavırlar ve iletişim isteği" olarak isimlendirilirken; 4 maddeden oluşan ve toplam varyansın \% 12,003' ünü açıklayan dördüncü faktör ise "Sözlü taciz ve aşağılama" olarak isimlendirilmiştir. 
Tablo 1: Cinsel Taciz Ölçeği Açıklayıcı Faktör Analizi

\begin{tabular}{|c|c|c|c|c|c|c|}
\hline & 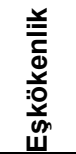 & 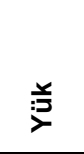 & 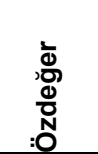 & 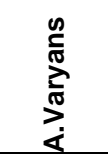 & 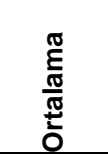 & $\stackrel{\text { I0 }}{\frac{\pi}{4}}$ \\
\hline $\begin{array}{l}\text { 1.İlgili Tavır ve Eylemler } \\
\text { (9 Madde) }\end{array}$ & & & 5,370 & 21,479 & 2,1900 & ,918 \\
\hline 7. Çalışma arkadaşlarım misafirler ile dışarı çıktılar. & ,686 &, 775 & & & 2,2934 & \\
\hline $\begin{array}{l}\text { 16. Misafirlerden hediyeler (ya da yüksek bahşişler) } \\
\text { aldım. }\end{array}$ &, 619 & ,752 & & & 2,3750 & \\
\hline $\begin{array}{l}\text { 17. Misafirler özellikle çok geç saatlerde içki siparişleri } \\
\text { verdiler. }\end{array}$ &, 572 &, 667 & & & 2,1786 & \\
\hline 9. Misafirlerin ilgili ve davetkar bakışlarıyla karşılaştım. & ,683 & 661 & & & 2,3393 & \\
\hline $\begin{array}{l}\text { 8. Çalışma arkadaşlarım misafirler ile cinsel birliktelik } \\
\text { yaşadılar. }\end{array}$ &, 614 &, 651 & & & 2,0298 & \\
\hline $\begin{array}{l}\text { 15. Misafirlerden yaptığım işle ilgili olmayan (fiziksel } \\
\text { özellikler vb.) iltifatlar aldım. }\end{array}$ &, 614 & ,649 & & & 2,2619 & \\
\hline 10.Misafirlerden davetkar işaretler aldım. & ,730 & ,598 & & & 2,0539 & \\
\hline $\begin{array}{l}\text { 11. Misafirlerin fiziğime ya da vücut hatlarıma dikkatle } \\
\text { baktığını fark ettim. }\end{array}$ &, 538 &, 588 & & & 2,2440 & \\
\hline $\begin{array}{l}\text { 14. Misafirlerin ısrarlı sosyal görüşme teklifleriyle (kahve, } \\
\text { içecek, buluşma vb.) karşılaştım. }\end{array}$ & ,701 &, 571 & & & 1,9345 & \\
\hline $\begin{array}{l}\text { 2.Bir Şey Karşılığında Bir Şey İsteme ve Fiziksel } \\
\text { Saldırı (6 Madde) }\end{array}$ & & & 4,757 & 19,026 & 1,1126 & ,927 \\
\hline $\begin{array}{l}\text { 29. Gelir durumu iyi olan misafirlerle cinsel faaliyetlerde } \\
\text { bulundum. }\end{array}$ & 779, & ,898 & & & 1,1257 & \\
\hline $\begin{array}{l}\text { 25. Misafirlerin iş için referans olması amacıyla cinsel } \\
\text { faaliyetlerde bulundum. }\end{array}$ & ,815 & ,890 & & & 1,0778 & \\
\hline $\begin{array}{l}\text { 27. Misafirlerin gösterdiği ilgi gururumu okşadığı için } \\
\text { cinsel faaliyetlerde bulundum. }\end{array}$ & ,814 & ,861 & & & 1,1437 & \\
\hline 33. Misafir tarafından tecavüze uğradım. & ,769 & ,856 & & & 1,0479 & \\
\hline $\begin{array}{l}\text { 28. Misafire aşık olduğum için cinsel faaliyetlerde } \\
\text { bulundum. }\end{array}$ &, 779 & ,810 & & & 1,1916 & \\
\hline $\begin{array}{l}\text { 24. Misafirlerden bahşiş almak için cinsel faaliyetlerde } \\
\text { bulundum. }\end{array}$ & ,674 & ,807 & & & 1,0893 & \\
\hline $\begin{array}{l}\text { 3.Müstehcen Tavırlar ve Íletişim İsteği } \\
\text { (6 Madde) }\end{array}$ & & & 2,242 & 16,968 & 1,7777 & ,896 \\
\hline $\begin{array}{l}\text { 21. Misafirler tarafından (bahaneyle ya da doğrudan) } \\
\text { odaya davet edildim. }\end{array}$ & ,678 & ,767 & & & 1,4762 & \\
\hline 23. Misafirlerin müstehcen teklifleriyle karşılaştım. & 651 &, 713 & & & 1,4762 & \\
\hline 1. Misafirler bana müstehcen sözler söylediler. & ,702 &, 675 & & & 1,7143 & \\
\hline 18. Misafirler kişisel telefon numaralarını verdiler. & ,737 &, 619 & & & 1,9458 & \\
\hline 19. Misafirler benim telefon numaramı istediler. & ,730 & ,595 & & & 2,0119 & \\
\hline $\begin{array}{l}\text { 3. Misafirlerin müstehcen şakalar ya da kişisel hikayeler } \\
\text { anlattığına tanık oldum. }\end{array}$ & ,623 &, 525 & & & 2,0419 & \\
\hline 4. Sözlü Taciz ve Aşağılama (4 Madde) & & & 3,001 & 12,003 & 1,7183 & ,838 \\
\hline $\begin{array}{l}\text { 5. Misafirlerden kadınları aşağılayan şakalar ya da sözler } \\
\text { duydum. }\end{array}$ & ,699 &, 769 & & & 1,7202 & \\
\hline $\begin{array}{l}\text { 6. Misafirlerden erkekleri aşağılayan şakalar ya da sözler } \\
\text { duydum. }\end{array}$ & ,615 &, 728 & & & 1,5536 & \\
\hline $\begin{array}{l}\text { 4. Misafirlerin çalışanlara müstehcen yorumlar yaptığına } \\
\text { tanık oldum. }\end{array}$ & ,752 &, 664 & & & 1,8795 & \\
\hline $\begin{array}{l}\text { 12. Misafirlerin cinsel alay, şaka, yorum ya da sorularıyla } \\
\text { karşılaşım. }\end{array}$ & ,735 &, 659 & & & 1,7202 & \\
\hline \multicolumn{7}{|c|}{$\begin{array}{l}\text { Faktör çıkarma metodu: Temel bileşenler analizi; Döndürme metodu: Varimax } \\
\text { Kaiser-Meyer-Olkin Örneklem Yeterliliği: ,884; Bartlett's Küresellik Testi için Ki-Kare: 3501,803; s.d.:, } \\
\text { p<0.0001; } \\
\text { Açıklanan toplam varyans: \%69,476; Ölçeğin tamamı için güvenirlik katsayısı: 0,944; Genel } \\
\text { ortalama:1,69965 } \\
\text { Yanıt kategorileri: 1: Hiç 2: Ara Sıra, 3:Bazen, 4:Coğunlukla, 5:Her Zaman }\end{array}$} \\
\hline
\end{tabular}


Madde ortalamaları incelendiğinde tüm maddelerin 1'in üzerinde ve 3' ün altında ortalamaya sahip olduğu görülmektedir. Madde ortalamalarının 1' den yüksek olması müşteriden çalışana yönelik tacizin yaşandığının kanıtı olarak kabul edilebilir. Ancak madde ortalamalarının hepsinin 3'ün altında olması misafirlerden çalışana yönelik cinsel tacizin çok yüksek oranda olmadığı şeklinde yorumlanabilir. Ancak madde ortalamalarına bakıldığında en sık rastlanan tacizin 'Misafirlerden hediyeler (ya da yüksek bahşişler) aldım.' (2,3750) maddesi olduğu, en az rastlanan cinsel tacizin ise 'Misafir tarafından tecavüze uğradım.' $(1,0479)$ maddesi olduğu bulgulanmıştır.

Misafirlerden cinsel taciz gören çalışanların bu davranışlardan duydukları rahatsızlıkla ilgili madde ortalamaları incelendiğinde tüm maddelerin 3' ün altında olduğu bulgulanmıştır. Bu bulgu çalışanların misafirlerden gördükleri cinsel tacizden ciddi olarak rahatsızlık duymadıkları veya biraz rahatsızlık duydukları şeklinde yorumlanabilir. En çok rahatsızlık duyulan cinsel taciz 'Misafirlerden hediyeler (ya da yüksek bahşişler) aldım.' (2,3750) maddesi olurken en az rahatsızlık duyulan cinsel taciz 'Misafir tarafından tehdit edildiğim için cinsel faaliyetlerde bulundum.' maddesi $(1,0120)$ olmuştur. Rahatsızlık boyutuna yönelik madde ortalamaları Tablo 2' de sunulmuştur.

\section{Tablo 2: Rahatsızlık Boyutu Madde Ortalamaları}

\begin{tabular}{|l|l|}
\hline & Ortalama \\
\hline 1. Misafirler bana müstehcen sözler söylediler. & 1,7143 \\
\hline 2. Misafirler bana cinsel içerikli materyaller (dergi, fotoğraf vb.) gösterdi. & 1,2381 \\
\hline 3. Misafirlerin müstehcen şakalar ya da kişisel hikayeler anlattığına tanık oldum. & 2,0419 \\
\hline 4. Misafirlerin çalışanlara müstehcen yorumlar yaptığına tanık oldum. & 1,8795 \\
\hline 5. Misafirlerden kadınları aşağılayan şakalar ya da sözler duydum. & 1,7202 \\
\hline 6. Misafirlerden erkekleri aşağılayan şakalar ya da sözler duydum. & 1,5536 \\
\hline 7. Çalışma arkadaşlarım misafirler ile dışarı ı̧ıktılar & 2,2934 \\
\hline 8. Çalışma arkadaşlarım misafirler ile cinsel birliktelik yaşadılar. & 2,0298 \\
\hline 9. Misafirlerin ilgili ve davetkar bakışlarıyla karşılaşım. & 2,3393 \\
\hline 10.Misafirlerden davetkar işaretler aldım. & 2,0539 \\
\hline 11. Misafirlerin fiziğime ya da vücut hatlarıma dikkatle baktığını fark ettim. & 2,2440 \\
\hline 12. Misafirlerin cinsel alay, şaka, yorum ya da sorularıyla karşılaştım. & 1,7202 \\
\hline 13. Misafirler bana kasıtı olarak dokundular ya da fiziksel temasta bulundular. & 1,5774 \\
\hline $\begin{array}{l}\text { 14. Misafirlerin ısrarlı sosyal görüşme teklifleriyle (kahve, içecek, buluşma vb.) } \\
\text { karşılaştım. }\end{array}$ & 1,9345 \\
\hline 15. Misafirlerden yaptığım işle ilgili olmayan (fiziksel özellikler vb.) iltifatlar aldım. & 2,2619 \\
\hline 16. Misafirlerden hediyeler (ya da yüksek bahşişler) aldım. & 2,3750 \\
\hline 17. Misafirler özellikle çok geç saatlerde içki siparişleri verdiler. & 2,1786 \\
\hline 18. Misafirler kişisel telefon numaralarını verdiler. & 1,9458 \\
\hline 19. Misafirler benim telefon numaramı istediler. & 2,0119 \\
\hline 20. Misafirlerin yurtdışına götürme teklifleriyle karşış̧ım. & 1,5952 \\
\hline 21. Misafirler tarafından (bahaneyle ya da doğrudan) odaya davet edildim. & 1,4762 \\
\hline $\begin{array}{l}\text { 22. Misafirler tarafından öpülmek, okşanmak, makas akmak gibi girişimlerle } \\
\text { karşılaştım. }\end{array}$ & 1,4405 \\
\hline 23. Misafirlerin müstehcen teklifleriyle karşılaştım. & 1,4762 \\
\hline
\end{tabular}


Tablo 2'nin Devamı

\begin{tabular}{|l|l|}
\hline 24. Misafirlerden bahşiş almak için cinsel faaliyetlerde bulundum. & 1,0893 \\
\hline 25. Misafirlerin iş için referans olması amacıyla cinsel faaliyetlerde bulundum. & 1,0778 \\
\hline 26. Misafir tarafından tehdit edildiğim için cinsel faaliyetlerde bulundum. & 1,0120 \\
\hline 27. Misafirlerin gösterdiği ilgi gururumu okşadığı için cinsel faaliyetlerde bulundum. & 1,1437 \\
\hline 28. Misafire aşık olduğum için cinsel faaliyetlerde bulundum. & 1,1916 \\
\hline 29. Gelir durumu iyi olan misafirlerle cinsel faaliyetlerde bulundum. & 1,1257 \\
\hline 30. Misafirlerle işimi elimde tutmak için cinsel faaliyetlerde bulundum. & 1,0719 \\
\hline 31. Misafirlerle istediğim için birlikte oldum. & 1,3795 \\
\hline 32. Misafirlerle değişik bir deneyim yaşamak için birlikte oldum. & 1,2216 \\
\hline 33. Misafir tarafından tecavüze uğradım. & 1,0479 \\
\hline
\end{tabular}

\section{2. Ölçeğe Ait Güvenilirlik Analizi}

Güvenilirlik analizi, ölçmede kullanılan testlerin, anketlerin ya da ölçeklerin özelliklerini ve güvenilirliklerini değerlendirmek üzere geliştirilmiş bir yöntemdir (Kalaycı, 2010: 403). Cinsel taciz ölçeğinin güvenilirliğini test etmek için Croanbach's Alpha katsayısı kullanılmıştır. Cinsel taciz ölçeğinin güvenilirlik katsayısı 0,944 olarak bulgulanmıştır. Ölçeğin birinci yarısı için güvenilirlik katsayısı 0,934 ; ikinci yarısı için 0,852 olarak bulgulanmıştır. Tek numaralı ölçek maddelerinin güvenilirlik katsayısı 0,900 ve çift numaralı ölçek maddelerinin güvenilirlik katsayısının 0,889 olduğu tespit edilmiştir. Rastgele seçilen 84 anket için güvenilirlik katsayısı 0,950; 93 anket için ise 0,944 olduğu bulgulanmıştır. Bu bilgiler ışığında ölçeğin yüksek derecede güvenilir olduğu söylenebilir (Kalaycı, 2010: 405). Ayrıca madde-bütün korelasyon değerinin negatif olmadığı ve 0,250' den büyük olduğu tespit edilmiştir. Ölçeğin güvenilirliğine ilişkin bulgular tablo 3' te sunulmuştur.

Tablo 3: Cinsel Taciz Ölçeğinin Güvenilirliğine İlişkin Bulgular

\begin{tabular}{|l|c|}
\hline \multicolumn{1}{|c|}{ Katsayıllar } & $\begin{array}{c}\text { Faktöre } \\
\text { Katılma Derecesi }\end{array}$ \\
\hline Madde sayısı & 25 \\
\hline Ölçeğin ilk yarısı için Alfa katsayısı & 0,934 \\
\hline Ölçeğin ikinci yarısı için Alfa katsayısı & 0,852 \\
\hline Tek numaralı ölçek maddeleri için Alfa katsayısı & 0,900 \\
\hline Çift numaralı ölçek maddeleri için Alfa katsayısı & 0,889 \\
\hline Rastgele seçilen 84 anket için Alfa katsayısı & 0,950 \\
\hline Rastgele seçilen 93 anket için Alfa katsayısı & 0,945 \\
\hline Tüm ölçek için Alfa katsayısı & 0,944 \\
\hline En küçük ve büyük madde-bütün korelasyon değeri & $0,258-0,811$ \\
\hline Negatif madde-bütün korelasyon değeri & Yok \\
\hline En küçük ve büyük çoklu R ${ }^{2}$ değeri & $0,399-0,861$ \\
\hline
\end{tabular}

\section{Katılımcılara İlişkin Bulgular}

Araştırmaya katılanların \%54,2' sini (91 kişi) erkekler oluşturmaktadır. Katılımcıların \%75' i (126 kişi) 18-24 yaş aralığındadır. Ayrıca araştırmaya katılanların \%52.38'i (88 
kişi) otelde servis departmanında çalışmış/staj yapmıştır. Demografik değişkenlere ilişkin bulgular Tablo 4' te sunulmuştur.

Tablo 4: Katılımcıların Demografik Değişkenlerine İlişkin Bulgular

\begin{tabular}{|lll|lll|}
\hline Cinsiyet & Frekans & $\%$ & Departman & Frekans & $\%$ \\
\hline Kadın & 76 & 45,2 & Ön büro & 31 & 18,45 \\
Erkek & 91 & 54,2 & Servis & 88 & 52,38 \\
Kayıp Veri & 1 & 6 & Mutfak & 6 & 3,57 \\
Toplam & 168 & 100 & Kat Hizmetleri & 8 & 4,76 \\
\cline { 1 - 2 } & Frekans & $\%$ & Diğer & 34 & 20,23 \\
\hline Yas-24 & 126 & 75 & Kayıp Veri & 1 & 0,59 \\
25 ve üzeri & 40 & 23,8 & Toplam & 168 & 100 \\
Kayıp Veri & 2 & 1,2 & & & \\
Toplam & 168 & 100 & & & \\
\hline
\end{tabular}

\subsection{Cinsel Taciz Ölçeğine Uygulanan T-Testi Sonuçları}

Otellerde staj yapan ya da çalışan öğrencilerin cinsel tacizle karşılaşma sıklığının cinsiyetlerine göre anlamlı bir farklılık gösterip göstermediğini ortaya çıkarmak amacıyla t-testi yapılmıştır. Yapılan t-testine göre öğrencilerin cinsel tacizin 1. 2. ve 3. alt boyutlarıyla karşılaşma sıklıklarının cinsiyetlerine göre anlamlı bir farklılık gösterdiği bulgulanmıştır $(p<0,05)$. T-testi sonuçları tablo 5 ' te sunulmuştur.

Tablo 5: Cinsel Tacizin Cinsiyet Yönünden Karşılaştırılması

\begin{tabular}{|c|c|c|c|c|c|c|c|}
\hline & Cinsiyet & $\mathbf{n}$ & Ortalama & $\begin{array}{l}\text { Standart } \\
\text { Sapma }\end{array}$ & $\begin{array}{c}T \\
\text { Değeri }\end{array}$ & $\begin{array}{l}\text { Anlam } \\
\text { Düzeyi }\end{array}$ & $\begin{array}{c}\text { Levene } \\
\text { Testi } \\
\text { p değeri }\end{array}$ \\
\hline \multirow{2}{*}{$\begin{array}{l}\text { İlgili Tavirlar ve } \\
\text { Eylemler }\end{array}$} & Kadın & 76 & 1,9216 & ,96524 & \multirow{2}{*}{$-3,115$} & \multirow{2}{*}{,002 } & \multirow{2}{*}{,633 } \\
\hline & Erkek & 91 & 2,4029 & 1,01790 & & & \\
\hline \multirow{2}{*}{$\begin{array}{l}\text { Bir Şey Karşılığında } \\
\text { Bir Şey Isteme ve } \\
\text { Fiziksel Saldırı }\end{array}$} & Kadın & 76 & 1,0154 & ,13383 & \multirow{2}{*}{$-2,794$} & \multirow{2}{*}{,006 } & \multirow{2}{*}{, 000} \\
\hline & Erkek & 91 & 1,1905 & ,57979 & & & \\
\hline \multirow{2}{*}{$\begin{array}{l}\text { Müstehcen Tavırlar } \\
\text { ve İletişim İsteği }\end{array}$} & Kadın & 76 & 1,5548 & 77335, & \multirow{2}{*}{$-2,960$} & \multirow{2}{*}{,004 } & \multirow{2}{*}{,040 } \\
\hline & Erkek & 91 & 1,9413 & ,91397 & & & \\
\hline \multirow{2}{*}{$\begin{array}{l}\text { Sözlü Taciz ve } \\
\text { Aşağılama }\end{array}$} & Kadın & 76 & 5,3372 & 2,89662 & \multirow{2}{*}{,- 914} & \multirow{2}{*}{,362 } & \multirow{2}{*}{, 540} \\
\hline & Erkek & 19 & $\begin{array}{r}5,7 \\
542\end{array}$ & $\begin{array}{r}2, \\
96485\end{array}$ & & & \\
\hline
\end{tabular}

Tablo incelendiğinde erkek katılımcılar cinsel tacizin ilk 3. alt boyutuna ('ilgili tavır ve eylemler', 'Bir şey karşılığında bir şey isteme', ve 'Müstehcen tavırlar ve iletişim isteği') kadın katılımcılardan daha yüksek ortalama atamışlardır. Ortalamalar incelendiğinde araştırmaya katılan erkek öğrencilerin kadın öğrencilere göre cinsel taciz ile daha sık karşılaştıkları söylenebilir.

Ayrıca tabloyla sunulmamakla birlikte araştırmanın bir diğer bulgusu 1 kadın, 3 erkek öğrencinin tecavüze uğramış olmasıdır. Kadın öğrenci çok fazla rahatsızlık 
duyduğunu belirtirken, 1 erkek öğrenci biraz rahatsızlık duyduğunu, 2 erkek öğrenci ise hiç rahatsız olmadıklarını belirtmişlerdir.

\section{Sonuç ve Öneriler}

Çalışma kapsamında Mersin Üniversitesi Turizm Fakültesi Turizm İşletmeciğinde öğrenim gören öğrencilerin çalıştıkları ya da staj yaptıkları otellerde uygunsuz davranışlarla karşılaşıp karşılaşmadıklarını ve eğer karşılaştılarsa bu davranışlardan ne derecede rahatsızlık duydukları incelenmiştir. Çalışmanın en önemli bulgularından bir tanesi erkek işgörenlerin kadın işgörenlere kıyasla cinsel tacizle daha sık karşılaşmalarıdır. Bu bulgu kadın işgörenlerin erkek işgörenlerden daha çok tacize uğradıkları genel toplumsal inancıyla örtüşmemektedir. Ancak, Wayne, Riordan ve Thomas' In (2001) cinsel tacizin kadınlardan erkeklere yönelik olarak da gerçekleşebildiği görüşüyle örtüşmektedir.

Webster (2002) ve Blumenthal (1998) erkeklerin kadınlara göre uygunsuz davranışlardan daha az rahatsız olduğunu belirtmiştir. Bu çalışmada tecavüze uğradığını belirten 1'i kadın 3'ü erkek 4 öğrenciden 2 erkek öğrencinin tecavüz olayından hiç rahatsızlık duymadığı bulgulanmıştır. Bu bulgu Webster (2002) ve Blumenthal (1998)'in bulgularıyla benzerlik gösterse de genel bir sonuca varmak için yeterli değildir. Bu konuda daha kapsayıcı araştırmalar yapılmasına intiyaç vardır.

Çalışma kapsamında ayrıca en sık karşılaşılan cinsel taciz davranışlarının misafirlerden yüksek bahşişler alma, misafirlerin davetkar bakışlarıyla karşılaşma, misafirlerden işle alakalı olmayan iltifatlar alma, misafirlerin işgörenlerin vücutlarına ya da vücut hatlarına dikkatle baktığını fark etme gibi davranışlar olduğu sonucuna varılmıştır. Ayrıca en çok rahatsızlık duyulan davranışların; misafirlerin kadınları ve erkekleri aşağılayan şakalar yapması ya da sözler söylemesi, misafirlerin özellikle geç saatlerde içki siparişleri vermesi, misafirlerin vücutlarına ya da vücut hatlarına dikkatle bakması ve müstehcen yorumlar yapılmasına tanıklık etmek olmuştur.

Mkono (2010) turizm işletmelerinde kadın çalışanların daha iyi bahşiş aldıkları için tacizi görmezden gelebildiklerini belirtmektedir. Bu çalışmada ise, 'Misafirlerden bahşiş almak için cinsel faaliyetlerde bulundum' maddesi katılımcıların karşılaştıkları rahatsız edici davranışlardan en az rahatsızlık duydukları maddelerden biri olarak belirlenmiştir. Her ne kadar iki çalışmanın bulguları birebir aynı olmasa da aralarındaki benzerlik dikkat çekicidir.

Araştırma sonuçları ciddi anlamda düşündürücüdür. Tacizin var olması ve bundan rahatsızlık duyulmaması işin doğası ya da gereği olarak görülüyor olabilir. Daha sonraki çalışmalarda öğrencilerin bu konudaki bakış açılarını belirlemeye yönelik daha kapsamlı çalışmalar yapılabilir.

Hizmet alanın ve hizmet edenin insan olduğu otel işletmelerinde müşterilerin personele karşı taciz davranışına yönelik mücadele için öncelikle taciz davranışın varlığının bilimsel olarak ortaya konması gerekir. Bu bağlamda, bu çalışma müşteriden personele yönelik taciz davranışının otel işletmelerinde yaşandığına ilişkin bulgular sunmaktadır. Dolayısıyla bu bulgular, otel yöneticileri açısından bir veri olarak kabul edilerek, gerekli önlemlerin alınmasına katkı sağlayabilir.

Bu çalışma yalnızca Mersin Üniversitesi Turizm Fakültesi öğrencileriyle Şubat 2017 - Mart 2017 tarihleri arasında gerçekleştirilmiştir. Çalışmanın farklı üniversitelerde 
farklı öğrenci gruplarıyla ve otel çalışanlarıyla tekrarlanması bu konudaki bilgi birikimine katkı yapabilir.

\section{Kaynakça}

Atman, Ü. C. (2003), 'Kadına Yönelik Şiddet; Cinsel Taciz / Irza Geçme' Sürekli Tıp Eğitim Dergisi, 12 (9), ss. 333-335.

Barling, J., Rogers, A. G. ve Kelloway, E. K. (2001), 'Behind Closed Doors: In-Home Workers' Experience of Sexual Harassment and Workplace Violence' Journal of Occupational Health Psychology, 6 (3), ss. 255-269.

Brase, G. L. ve Miller, R. L. (2001), 'Differences in the Perception of and Reasoning About Quid Pro Quo Sexual Harassment' Psychology, Evolution \& Gender, 3 (3), ss. 241-264.

Blumenthal, J. A. (1998), 'The Reasonable Woman Standard: A Meta-Analytic Review Of Gender Differences In Perceptions Of Sexual Harassment' Law and Human Behavior, 22, ss. 33- 57.

Chan, D. K. S., Lam, C. B., Chow, S. Y. ve Cheung, S. F. (2008), 'Examining the JobRelated, Psychological, and Physical Outcomes of Workplace Sexual Harassment: A Meta-Analytic Review' Psychology of Women Quarterly, 32, ss. 362-376.

Coles, F. S. (1986), 'Forced To Quit: Sexual Harassment Complaints and Agency Response' Sex Roles, 14 (1/2), ss. 81-95.

Crull, P. (1982), 'Stress Effects of Sexual Harassment on the Job: Implications for Counseling' Amer. J. Orthopsychiat, 52 (3), ss. 539-544.

Erdemir, F., Akgün, Çıtak, E., Ulusoy, H. ve Geçkil E. (2011), 'Hemşirelerin Hastalar Tarafından Cinsel Tacize Uğrama Durumlarının Belirlenmesi' Hacettepe Üniversitesi Sağlık Bilimleri. Fakültesi Hemşirelik Dergisi, 18 (2), ss. 27-35.

European Foundation for the Improvement of Living and Working Conditions. (2007), Fourth European working conditions survey. Danimarka.

Eyüpoğlu, H. (2008), 'Cinsel Taciz ve Travma: Eleştirel Bir Deneyim Aktarımı' Eleştirel Psikoloji Bülteni, 1, ss. 61-68.

Fitzgerald, L. F., Drasgow, F., Hulin, C. L., Gelfand, M. J. ve Magley, V. J. (1997), 'Antecedents and Consequences of Sexual Harassment in Organizations: A Test of an Integrated Model' Journal of Applied Psychology, 82 (4), ss. 578-589.

Gerni, M. (2001), 'İşyerinde Cinsel Taciz: Erzurum İlinde Bankacılık Sektörü Üzerine Bir Uygulama' Ankara Üniversitesi SBF Dergisi, 56 (3), ss. 19-46.

Gilbert, D., Guerrier, Y. ve Guy, J. (1998), 'Sexual Harassment Issues in the Hospitality industry' International Journal of Contemporary Hospitality Management, 10 (2), ss. 48-53.

Gölge, Z. B. (2005), 'Cinsel Travma Sonrası Oluşan Ruhsal Sorunlar' Nöropsikiyatri Arşivi, 42 (1-2-3-4), ss. 19-28.

Harned, M. S., Ormerod, A. J., Palmieri, P. A., Collinsworth, L. L. ve Reed, M. (2002), 'Sexual assault and other types of sexual harassment by workplace personnel: A comparison of antecedents and consequences' Journal of Occupational Health Psychology, 7 (2), ss. 174-188.

Ural, A. ve Kılıç, I. (2011), Bilimsel Araştırma Süreci ve SPSS ile Veri Analizi, Ankara, Detay Yayıncılık.

Hughes, K. D. ve Tadic, V. (1998), "Something to Deal with': Customer Sexual Harassment and Women's Retail Service Work in Canada' Gender, Work and Organization, 5 (4), ss. 207-219,

Husbands, R. (1992), 'Sexual Harassment Law in Employment' International Labour Review, 131 (6), ss. 535-559. 
Kalaycı, Ş. (2010), SPSS uygulamalı çok değişkenli istatistik teknikleri. Ankara, Asil Yayın Dağıtım.

Kane-Urrabazo, C. (2007), 'Sexual Harassment in the Workplace: It is Your Problem' Journal of Nursing Management, 15, ss. 608-613.

Kauppınen-Toropaınen, K. ve Gruber, J. E. (1993), 'Antecedents and Outcomes of Woman-Unfriendly Experiences: A Study of Scandinavian, Former Soviet, and American Women' Psychology of Women Quarterly, 17, ss. 431-456.

Lin, Y. (2006), 'The Incidence of Sexual Harassment of Students while Undergoing Practicum Training Experience in the Taiwanese Hospitality IndustryIndividuals Reactions and Relationships to Perpetrators' Tourism Management, 27, ss. 51-68.

Lu, C. ve Kleiner, B. (2001), 'Discrimination and Harassment in the Restaurant Industry' International Journal of Sociology Policy, 21 (8), ss. 191-204.

Luthar, V. K. ve Luthar, H. (2002), 'Using Hofstede's Cultural Dimensions to Explain Sexually Harassing Behaviours in an International Context' Int. J. of Human Resource Management, 13 (2), ss. 268-284.

Luthar, V. K. ve Luthar, H. (2007), 'A Theoretical Framework Explaining Cross-Cultural Sexual Harassment: Integrating Hofstede and Schwartz' Journal Of Labor Research, 28, ss. 169-188.

Maypole, D. E. ve Skaine, R. (1983), 'Sexual Harassment in the Workplace' Social Work. 28, ss. 385-390.

Mimaroğlu, H. ve Özgen, H. (2008), 'Örgütlerde Güç Eşitsizlikleri ve Taciz’ Ç.Ü. Sosyal Bilimler Enstitüsü Dergisi, 17 (1), ss. 321-334.

Mkono, M. (2010), 'Zimbabwean Hospitality Students' Experiences of Sexual Harassment in the Hotel Industry' International Journal of Hospitality Management, 29(1), ss. 729-735.

O'Farrell, B. ve Harlan, S. L. (1982), 'Craftworkers and Clerks: The Effects of Male Coworker Hostility on Women's Satisfaction with Nontraditional Jobs' Social Problems, 29, ss. 252-264.

Oktay, A. (2012), 'İ̧yerinde Cinsel Taciz ve İstismar' Kadın Araştırmaları Dergisi, 0 (7), ss. $75-89$.

Özdemir, E. (2006), 'İşyerinde Cinsel Taciz' Çalışma ve Toplum, 4, ss. 83-96.

Quinn, R. E. ve Lees, P. L. (1984), 'Attraction and Harassment: Dynamics of Sexual Politics in the Workplace' Organizational Dynamics, 13, ss. 35-46.

Poulston, J. (2008), 'Metamorphosis in Hospitality: A Tradition of Sexual Harassment' International Journal of Hospitality Management, 27, ss. 232-240.

Powell, G. N. (1983), 'Definition of Sexual Harassment and Sexual Attention Experienced' The Journal of Psychology, 113, ss. 113-117.

Robbins, S. P. ve Judge, T. A. (2012), Organizational Behavior (15th Edition), Pearson.

Schneider, K. T., Swan, S. ve Fitzgerald, L. F. (1997), 'Job-Related and Psychological Effects of Sexual Harassment in the Workplace: Empirical Evidence from Two Organizations' Journal of Applied Psychology, 82 (3), ss. 401-415.

Sherwyn, D. D., Sturman, M. M., Eigen, Z. J., Heise, M. ve Walwyn, J. (2001), 'The Perversity of Sexual-Harassment Law' The Cornell Hotel and Restaurant Administration Quarterly, 42 (3), ss. 46-56.

Solmuş, T. (2005), 'İş Yaşamında Travmalar: Cinsel Taciz ve Duygusal Zorbalık/Taciz (Mobbing)' '̇ş, Güç Endüstri Illişkileri ve Insan Kaynakları Dergisi, 7 (2), ss. 1-14.

TDK. (2017). http://www.tdk.gov.tr/. (23.04.2017).

TUiK. (2008). http://www.tuik.gov.tr/. (23.04.2017).

Wasti, S. A ve Cortina, L. M. (2002), 'Coping in Context: Sociocultural Determinants of Responses to Sexual Harassment' Journal of Personality and Social Psychology, 83 (2), ss. 394-405. 
Wayne, J. H., Riordan, C. M. ve Thomas, K. M. (2001), 'Is All Sexual Harassment Viewed The Same? Mock Juror Decisions in Same- and Cross-Gender Cases' Journal of Applied Psychology, 86 (2), ss. 179-187.

Webster, A. J. (2002), 'Sexual Harassment: Do Perceptions Differ Across Race and Sex?' McNair Scholars Journal, 6 (1), ss. 117-125.

Williams, C. L., Giuffre, P. A. ve Dellinger, K. (1999), 'Sexuality in the Workplace: Organisational Control, Sexual Harassment and the Pursuit of Pleasure' Annual Review of Sociology, 25, ss. 73-93.

Yagil, D. (2008), 'When the Customer is Wrong: A Review of Research on Aggression and Sexual Harassment in Service Encounters' Aggression and Violent Behavior, 13, ss. 141-152.

Yeşiltaş, M. (2005), 'İnsan Kaynakları Yönetimi Açısından Bir Sorun Olarak İşyerinde Cinsel Taciz' Kırgızistan-Türkiye Manas Üniversitesi Manas Sosyal Bilimler Dergisi, 13 (1), ss. 147-154.

Yücel, E. B. ve Koparan, E. (2010), 'Güç Mesafesi ve Cinsel Taciz Davranışları Arasındaki İlişkinin Yönünü Belirlemeye Yönelik Görgül Bir Çalışma' Organizasyon ve Yönetim Bilimleri Dergisi, 2 (1), ss. 11-18. 